\title{
Prostate tumor growth is driven by increased cholesterol and steroid production
}

Hannes Neuwirt, MD, PhD

Jan Bouchal, PhD

Gvantsa Kharaishvili, PhD

Christian Ploner, PhD

Karin Jöhrer, PhD

Florian Pitterl, PhD

Anja Weber, PhD

Helmut Klocker, PhD

Iris E Eder, PhD Assoc Prof

\section{Video Byte}

Keywords: prostate cancer, tumor, growth, fibroblasts, PCa, CAFs, cancer-associated fibroblasts, cholesterol, steroid, genetics

Posted Date: February 14th, 2020

DOI: https://doi.org/10.21203/rs.2.23787/v1

License: (c) (i) This work is licensed under a Creative Commons Attribution 4.0 International License. Read Full License 


\section{Abstract}

More than 1 million men are diagnosed with prostate cancer each year Although effective therapies exist, resistance to androgen receptor-targeted therapy is a major challenge in managing the disease Unfortunately, the mechanisms behind therapy resistance are not yet fully understood In a recent study, researchers aimed to identify new targets for treatment against therapy-resistant prostate cancer Using gene expression analysis and 3-dimensional spheroid culture, they examined the interaction of prostate cancer (PCa) cells with cancer-associated fibroblasts (CAFs) The results showed that CAFs in the tumor environment stimulate cholesterol and steroid production in PCa cells This was mediated by proinflammatory, pro-migratory, and pro-angiogenic factors secreted by the CAFs, which upregulated genes involved in cholesterol synthesis Blocking cholesterol and steroid production using gene targeting or medication inhibited PCa cell growth Future studies will evaluate the mechanisms underlying the interaction between tumor cells and their microenvironment But the results suggest that combined therapy to block cholesterol metabolism and steroid biosynthesis together may be a promising approach to target androgen receptor therapy-resistant cancer cells 